\title{
Historical and Future Spatial and Temporal Changes in Land Use and Land Cover in the Little Ruaha River Catchment, Tanzania
}

\author{
Nyemo A. Chilagane ${ }^{1 *}$, Japhet J. Kashaigili ${ }^{1}$, Edmund Mutayoba ${ }^{2}$ \\ ${ }^{1}$ Department of Forest Resources Assessment and Management, Sokoine University of Agriculture, Morogoro, Tanzania \\ ${ }^{2}$ Department of Chemical Processing and Environmental Engineering, Mbeya University of Science and Technology, Mbeya, Tanzania \\ Email: ^nchilagane@yahoo.com, jkashaigili@sua.ac.tz, edmundmutayoba@yahoo.com
}

How to cite this paper: Chilagane, N. A., Kashaigili, J. J., \& Mutayoba, E. (2020). Historical and Future Spatial and Temporal Changes in Land Use and Land Cover in the Little Ruaha River Catchment, Tanzania. Journal of Geoscience and Environment Protection, 8, 76-96.

https://doi.org/10.4236/gep.2020.82006

Received: January 17, 2019

Accepted: February 8, 2020

Published: February 11, 2020

Copyright $\odot 2020$ by author(s) and Scientific Research Publishing Inc. This work is licensed under the Creative Commons Attribution International License (CC BY 4.0).

http://creativecommons.org/licenses/by/4.0/

(c) (i) Open Access

\begin{abstract}
Increased anthropogenic activities in the Little Ruaha River Catchment have modulated the catchment condition, nevertheless, the future changes as a result of increased anthropogenic activities are unknown. Understanding the future changes is vitally important for the design of appropriate strategies towards sustainable management of the catchment resources. This study applied Remote Sensing and GIS techniques (Jensen \& Lulla, 1987) to assess the historical long-term changes in land use and land cover using Landsat satellite images of 1990, 2005 and 2015, and modelled the future change in land use and land cover up to 2040 using the stochastic CA-Markov chain (Almeida et al., 2005). The historical land use and land cover change detection results indicate that between 1990 and 2005 the area under forest changed from 39,872 ha to 22,957 ha, woodland changed from 109,692 ha to 72,809 ha, wetland decreased from 19,157 ha to 11,785 ha, the cultivated land increased from 106,782 ha to 109,047 ha, likewise, the built-up area increased from 9408 ha to 11,674 ha. Results between 2005 and 2015 show the substantial changes where the forest decline from 22,957 ha to 15,950 ha, woodland decreased from 72,809 ha to 58,554 ha and the wetland changed from 11,785 ha to 5622 ha. Cultivated land and built up area increased from 109,047 ha and 11,674 ha to 143,468 ha and 13,765 ha respectively. Generally, the study has revealed the substantial decline in forest, woodland and wetland by 23,922 ha, 51,138 ha and 13,535 ha respectively, and an increase of cultivated land and built up area by 36,668 ha and 4357 ha respectively in 15 years, between 1990 and 2015. The predicted future land use and cover for the next 15 years (2040) showed an overall increase in cultivated land, built up area, grassland and bushland to $24.82 \%, 2.24 \%, 25.18 \%$ and $20.41 \%$ respectively, and a decrease in forest, woodland and wetland in the order of $1.87 \%, 7.87 \%$ and
\end{abstract}


$0.03 \%$ respectively. The study concludes that, there have been significant changes in land use and cover in the catchment which likely to impend the sustainability of the catchment productivity, hence recommends the holistic system thinking and analysis approach in management and utilization of catchment resources.

\section{Keywords}

GIS, Little Ruaha River, CA Markov Chain, Land Use and Land Cover, Remote Sensing, Tanzania

\section{Introduction}

The major changes in land use and land cover (LULC) are a result of natural resources utilization. In most of the African countries, particularly in the Sub-Saharan Africa, their livelihood depends on the utilization of natural resources particularly from the forest and wetlands (Adger, 2007; Majule, 2013). This dependency tied with anthropogenic activities have been going on and intensified during the past millennium (Soka \& Nzunda, 2014). The continued utilization to meet human needs has resulted in an observable pattern of change in the context of land use and land cover over time. Amongst the impacts is the alteration in the availability of diverse biophysical resources such as soil, vegetation, water and pasture (Ohri \& Poonam, 2012). The vegetation cover is one of the important factors which partitions the rainfall into various hydrologic components such as surface runoff, base flow, ground water flow, evapotranspiration, etc., Therefore, the land use change pattern studies play a paramount role in catchment management and hydrological modelling (Lin et al., 2008).

Land use and land cover changes have become a major challenge on the sustainability of the Little Ruaha River catchment (Milder et al., 2013). Land cover change is expected to alter regional hydrologic conditions and results in varieties of impacts on ecosystem functioning ( $\mathrm{Li}$ et al., 2007) especially river ecosystem. Hydrological alteration of Little Ruaha River catchment is believed to negatively impact not only on the livelihood of people through decreased crop and livestock production (Milder et al., 2013), but also on national economy by impacting the biological diversity of Ruaha National Park as well as sedimentation of Hydroelectric power stations (Buck, 2012).

This paper reports on a case study that has been conducted to understand the changes in land use and land cover in Little Ruaha River Catchment, Tanzania for the periods 1990 and 2015, and the predicted the future changes in LULC up to 2040. The catchment is known for its ecological and economical potentiality and a source of freshwater supply and irrigation for many residents in the rural and urban settlements of the neighboring districts. Also, it is a major source of water for the Ihemi Cluster, which is one of the six clusters identified by the Southern Agricultural Growth Corridor of Tanzania (SAGCOT) (Milder et al., 2013) 
for agricultural intensification with significant investments in irrigation (Milder et al., 2012). It is believed that aggressive exploitation of the land in the catchment might have affected the land use and land cover pattern and that the changes will be gigantic in the near future following planned development in the catchment. Therefore, this study was conducted to not only to provide understanding on the spatial-temporal dynamics of land use and land cover but also to give baseline information for further study on how land use and land cover change can impact hydrological response and other ecosystem services of the Little Ruaha River catchment.

\section{Materials and Methods}

\subsection{Description of the Study Area}

This study was conducted in the Little Ruaha River catchment, one of the three tributaries forming the Great Ruaha River Catchment (GRRC) (Figure 1). Geographically the catchment lies within longitudes $35^{\circ} 2^{\prime} \mathrm{E}$ and $35^{\circ} 36^{\prime} \mathrm{E}$ and, latitudes $7^{\circ} 11^{\prime} \mathrm{S}$ and $8^{\circ} 36^{\prime} \mathrm{S}$. Little Ruaha River catchment has been estimated to have $6300 \mathrm{~km}^{2}$ catchment area and drains parts of Iringa Municipal, Iringa, Kilolo and Mufindi Districts in Iringa Region. The catchment lies within the Ihemi Cluster, one of the six clusters forming the Southern Agricultural Growth Corridor of Tanzania (SAGCOT). Climate in the catchment is highly variable, at both spatial and temporal scales, and is dominantly unimodal with a single rainy season from November to April and correlated with altitude. Average annual rainfall ranges from $500 \mathrm{~mm}$ in the lowlands (e.g. rainfall measured at Mtera Met station) to $700 \mathrm{~mm}$ in the highlands at Iringa based on average rainfall from 1979 to 2012. The mean annual temperature varies from about $18^{\circ} \mathrm{C}$ at higher altitudes to about $28^{\circ} \mathrm{C}$. Elevation ranges from 698 to over $2300 \mathrm{~m}$, above mean sea level (m·asl) (Figure 1). Dominant soils in the area include Cambisols, Fluvisols, Leptosols, Lixisols, Nitisols and Solonetz.

\subsection{Methods}

\subsubsection{Data Collection, Tools and Techniques}

Appropriate satellite imagery acquisition was done with highly consideration of cloud cover, the seasonality and phonological effects (Kashaigili et al., 2006). Clouds free satellite images with the interval not less than ten years from 1990 to 2015 (Table 1) sourced from USGS-GLOVIS (https://glovis.usgs.gov/) were used in assessing temporal and spatial variation of land use/cover change in the study area.

\subsubsection{Data Processing and Analysis}

To ensure accurate identification of temporal changes and geometric compatibility with other sources of information, images were pre-processed whereby geo-correction was conducted to rectify precisely matching of images. Band stacking and image enhancement was performed using different color composite band combinations to reinforce the tonal distinctions. Images were registered to the 


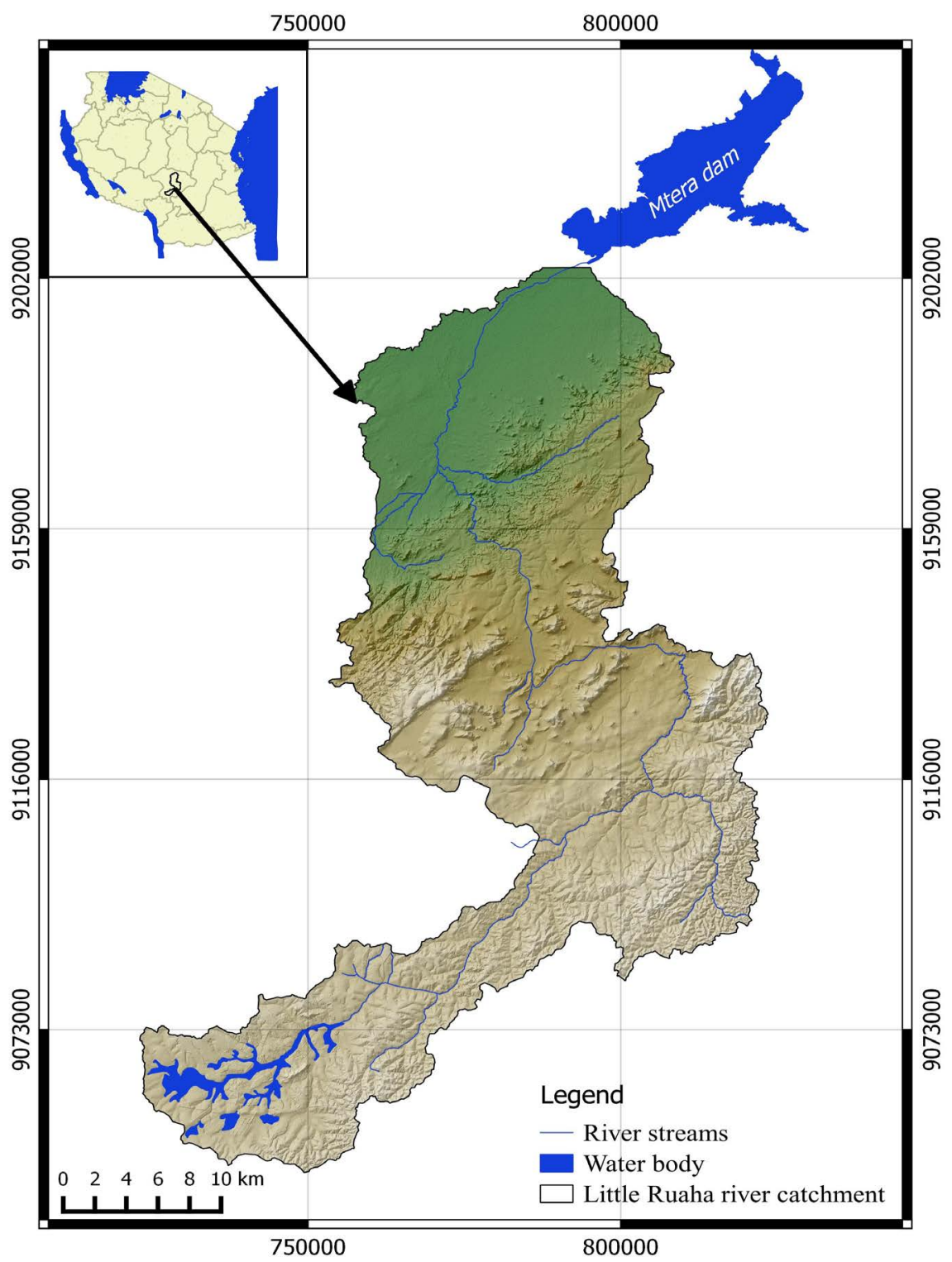

Figure 1. Little Ruaha River catchment.

Table 1. Satellite imagery data used in analysis of land use and land cover change.

\begin{tabular}{cccccc}
\hline Satellite & Sensor & Path/Row & Acquisition date & Season & Cloud cover (\%) \\
\hline Landsat 5 & TM & $168 / 65$ & July 11, 1990 & Dry & 0 \\
Landsat 5 & TM & $168 / 66$ & July 11, 1990 & Dry & 0 \\
Landsat 5 & TM & $168 / 65$ & July 20, 2005 & Dry & 6 \\
Landsat 5 & TM & $168 / 66$ & July 7, 2005 & Dry & 6 \\
Landsat 8 & OLI-TIRS & $168 / 65$ & October 4, 2015 & Dry & 9.78 \\
Landsat 8 & OLI-TIRS & $168 / 66$ & October 21, 2015 & Dry & 0.03 \\
\hline
\end{tabular}

Universal Transverse Mercator (UTM) map coordinate system, Zone 36 South, Datum Arc 1960 (Arc 1960/UTM zone 36S). Image mosaic was conducted to merge together images of the same year with same path and different row so as to create a single image that covers the entire catchment (Figure 2). 


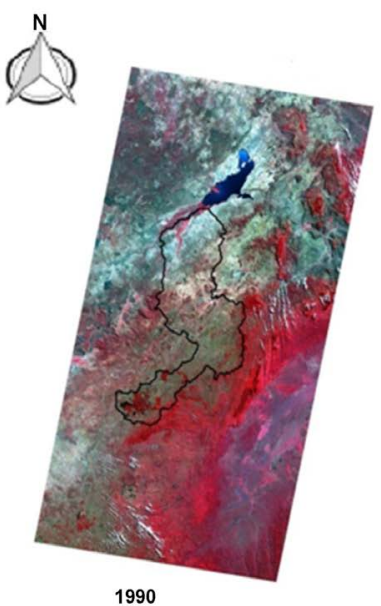

1990
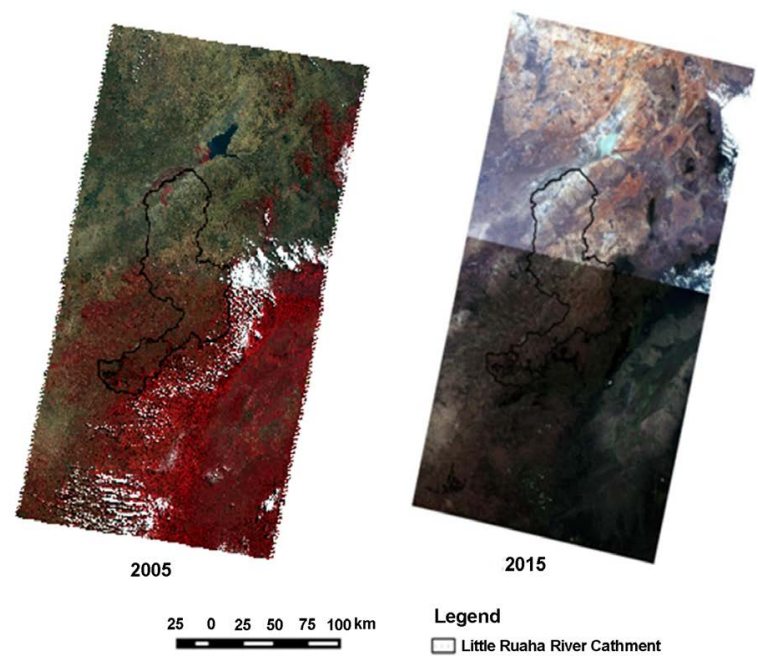

Figure 2. Mosaicked images with overlaid LRRC boundary.

Supervised image classification using Maximum Likelihood Classifier (MLC) was conducted to classify the images. Maximum likelihood classifier is one of the most popular classification algorithms which calculates posterior probability of a pixel belonging into corresponding class based on Bayes theorem (Congedo, 2016). The algorithm used probability density functions to assigns the pixel to the most likely (highest probability value) class (Lillesand \& Kiefer, 2002) which increase the accuracy of classification output to resemble to the real world. A base-map for year 2015 was created and used for ground truthing fieldwork. The basis of land cover type nomenclature adopted "The National Forest Resources Monitoring and Assessment (NAFORMA) Field Manual Biophysical survey of 2010" with few modifications to reflect the actual ground conditions (Table 2).

The training sites for MLC were identified by inspecting an enhanced color composite imagery. Areas with similar spectral characteristics were trained and assigned respective classes. The Semi-automatic Classification Plugin (SCP) available in QGIS 2.12.1 was applied to classify the image into twelve distinct land cover classes.

Ground truthing was conducted using a hand-held Global Positioning System (GPS) with a base-map of year 2015. The essence of conducting ground truthing was to verify different covers types as described on the base maps and for collection of ground points for the classification accuracy assessment. The error matrices (Congalton, 1991) were prepared and used in computation of Kappa coefficient $(K)$ for the classification accuracy assessment of final image classification. The probability of a classified land cover map corresponds accurately with the ground truthing data assessed by the user's accuracy (Jansen, 2004) and the measures of the agreement of classified maps and ground truthing data assessed by Kappa statistics (Lillesand et al., 2014).

$$
K=\frac{\sum_{i=1}^{r} x_{i i}-\sum_{i=1}^{r}\left(x_{i+} \times x_{+i}\right)}{N^{2}-\sum_{i=1}^{r}\left(x_{i+} \times x_{+i}\right)}
$$


Table 2. Land use and land cover classification scheme.

\begin{tabular}{|c|c|}
\hline Land cover & Description \\
\hline Forest & $\begin{array}{l}\text { Land covered with naturally regenerated native tree species with no clearly } \\
\text { visible indications of human activities }\end{array}$ \\
\hline Plantation & $\begin{array}{l}\text { Artificially established forested area/cultivated land by planting or seeding } \\
\text { (Plantation forest, tree farms, woodlots and Tea plantation) }\end{array}$ \\
\hline Riverine forest & $\begin{array}{l}\text { Forested area adjacent flowing bodies of water such as river, streams } \\
\text { and dams }\end{array}$ \\
\hline Lake/Dam & $\begin{array}{l}\text { Area within body of land, of variable size, filled with water, localized in a } \\
\text { basin, which rivers flow into or out of them. }\end{array}$ \\
\hline Wetland & Land area that is saturated with water either permanent or seasonally \\
\hline Woodland & $\begin{array}{l}\text { Area of land covered low density trees forming open habitat with plenty of } \\
\text { sunlight and limited shade }\end{array}$ \\
\hline Wooded rock & $\begin{array}{l}\text { Area of land covered with low density trees in a visible exposed } \\
\text { mineral rock }\end{array}$ \\
\hline Cultivated woodland & $\begin{array}{l}\text { Area of land covered with low density and scattered trees with crop } \\
\text { cultivation activities }\end{array}$ \\
\hline Grassland & Land area dominated by grasses \\
\hline Bushland & Area dominated with bushes and shrubs \\
\hline Cultivated land & Farm with crops and harvested cropland \\
\hline Built up land & $\begin{array}{l}\text { Man-made infrastructures (roads and buildings) and settlement } \\
\text { (cities and villages) }\end{array}$ \\
\hline
\end{tabular}

where $N$ is the total number of sites in the matrix, $r$ is the number of rows in the matrix, $x_{i i}$ is the number in row $i$ and column $i, X_{+i}$ is the total for row $i$, and $x_{i+}$ is the total for column.

To analyses the changes between different time epochs, change detection analysis was performed. Post classification comparison was used to quantify the extent of land cover changes for the periods 1990, 2005 and 2015. The estimation for the rate of change for the different land covers was computed based on (Kashaigili \& Majaliwa, 2010).

$$
\begin{gathered}
\text { \%Cover change }=\frac{\text { Area }_{i \text { year } x}-\text { Area }_{i \text { year } x+1}}{\sum_{i=1}^{n} \text { Area }_{i \text { year } x}} \times 100 \\
\text { Annual rate of change }=\frac{\text { Area }_{i \text { year } x}-\text { Area }_{i \text { year } x+1}}{t_{\text {years }}} \\
\text { \%Annual rate of change }=\frac{\text { Area }_{i \text { year } x}-\text { Area }_{i \text { year } x+1}}{\text { Area }_{i \text { year } x} \times t_{\text {years }}} \times 100
\end{gathered}
$$

Area $_{i \text { year } x}$ is the area in hectares (ha) of cover $i$ at the first date;

Area $_{i \text { year } x+1}$ is the area in hectares (ha) of cover $i$ at the second date;

$\sum_{i=1}^{n}$ Area $_{i \text { year } x}$ is the total cover area at the first;

$t_{\text {years }}$ is the period in years between the first and second scene acquisition dates. 


\subsubsection{Prediction of Future LULCC Using Cellular Automata-Markov Chain}

Markov chain is a statistical tool that describes the probability of land use to change from one time period to another by developing a transitional probability matrix between first period and second period based on the spatial neighborhood effects (Wang et al., 2004; Al-Bakri et al., 2013; Araya \& Cabral, 2010). A spatial neighborhood effect is the state of neighboring cells to influence the transition of a given cell into different states. This model was based on using and evaluating land use layers of previous years to predicting the spatial distribution of land uses in the future (Wu \& Silva, 2010). For better simulation of temporal and spatial patterns of land use changes in quantity and space, the combination of two techniques Markov chain analysis and Cellular automata (CA-Markov) were used.

The simulated model was developed by using IDRISI Selva v.17.0 software (Rutherford et al., 2015) and it involved two main stages which are calculating conversion probability (conversion probability matrix, conversion area matrix and layers of conditional probability) done by using Markov chain analysis, and the second stage was spatial specification of land use coverage simulated based on Cellular Automata spatial operator and multi criteria evaluation (MCE).

\subsubsection{CA-Markov Model Set up}

In the developing CA Markov model, the classified land use map of 1990 which represent past, and 2015 which represent present time developed in QGIS 2.12.1 were converted into IDRISI data format and selected to be input data into the model, to calculate matrices of conversion probabilities and conversion areas (Transition area matrix and transition probability matrix).

The transition probability matrix (Table 3 ) expresses the likelihood (probability) that a pixel of a given class that will change to any other class (or stay the same) in the next time period. The transition areas matrix (Table 4) expresses the total area (in cells) expected to change from the year 2015 to the year of 2040 according to those changes happened from 1990 to 2015.

\subsubsection{CA-Markov Model Validation}

For model validation the simulated land use/cover map for 2015 was compared with the actual satellite derived land use/cover map based on the Kappa statistics. Then, standard Kappa index was used to check whether the model is valid or not (usually the Kappa Index for a valid model is $>70 \%$ ) (Wen, 2008). If the model has the Kappa Index less than $70 \%$ then the suitability map for the land covers and filter used should be repeated based on several considerations. VALIDATE tool was used to compute Kappa statistics for the projected land use/cover.

\section{Results}

\subsection{Land Use and Land Cover Change Assessment}

\subsubsection{Accuracy}

The classified maps showed good agreement with the real world as indicated by 
Table 3. Transitional probability matrix for land use/cover change 1990/2015.

\begin{tabular}{|c|c|c|c|c|c|c|c|c|c|c|c|c|}
\hline \multirow[t]{2}{*}{ Given } & \multicolumn{12}{|c|}{ Probability of a cell to change (transition) to: } \\
\hline & FR & PL & RF & WTR & WET & WD & WR & $\mathrm{CW}$ & GR & BS & CLT & BLT \\
\hline FR & 0.1718 & 0.1248 & 0.0001 & 0.0001 & 0 & 0.0169 & 0.0031 & 0.4205 & 0.0703 & 0.0301 & 0.1571 & 0.0051 \\
\hline PL & 0.1113 & 0.3571 & 0.0001 & 0.0001 & 0 & 0.0057 & 0.001 & 0.1464 & 0.1619 & 0.0251 & 0.1825 & 0.009 \\
\hline $\mathrm{RF}$ & 0.0147 & 0.0046 & 0.0704 & 0.0008 & 0.0311 & 0.0858 & 0.0796 & 0.0153 & 0.2 & 0.1274 & 0.3372 & 0.0332 \\
\hline WTR & 0.0017 & 0.0054 & 0.0006 & 0.292 & 0.2311 & 0.0332 & 0.0388 & 0.0001 & 0.0906 & 0.2089 & 0.0758 & 0.0216 \\
\hline WET & 0.0134 & 0.0852 & 0.0006 & 0.002 & 0.1421 & 0.0786 & 0.0917 & 0.0458 & 0.1622 & 0.2277 & 0.1417 & 0.0093 \\
\hline WD & 0.005 & 0.0039 & 0.0048 & 0.0001 & 0.0052 & 0.232 & 0.1841 & 0.0065 & 0.1879 & 0.2305 & 0.1116 & 0.0286 \\
\hline WR & 0.0087 & 0.0072 & 0.0006 & 0 & 0.0003 & 0.0444 & 0.1381 & 0.032 & 0.2147 & 0.3533 & 0.1626 & 0.0381 \\
\hline CW & 0.0345 & 0.0435 & 0 & 0 & 0.0001 & 0.0289 & 0.0166 & 0.2501 & 0.1603 & 0.1073 & 0.3354 & 0.0234 \\
\hline GR & 0.007 & 0.0216 & 0 & 0 & 0.0061 & 0.0555 & 0.0388 & 0.0408 & 0.3625 & 0.1908 & 0.255 & 0.0217 \\
\hline BS & 0.0117 & 0.0306 & 0 & 0 & 0.0008 & 0.1143 & 0.0373 & 0.0905 & 0.2273 & 0.2597 & 0.2189 & 0.0089 \\
\hline CLT & 0.0086 & 0.012 & 0.0002 & 0 & 0.0033 & 0.0571 & 0.0418 & 0.0419 & 0.2712 & 0.2064 & 0.3344 & 0.0231 \\
\hline BLT & 0.0051 & 0.005 & 0.0015 & 0 & 0.0285 & 0.0897 & 0.0357 & 0.0205 & 0.2543 & 0.1329 & 0.3151 & 0.1116 \\
\hline
\end{tabular}

FR: Forest, PL: Plantation, RF: Riverine forest, WTR: Water, WET: Wetland, WD: Woodland, GR: Grassland, WR: Wooded rock, CW: Cultivated woodland, BS: Bushl, CLT: Cultivated land, BLT: Built up.

Table 4. Transitional area matrix for land use/cover change between 1990/2015.

\begin{tabular}{|c|c|c|c|c|c|c|c|c|c|c|c|c|}
\hline \multirow{2}{*}{$\begin{array}{c}\text { Cell } \\
\text { in } 1990\end{array}$} & \multicolumn{12}{|c|}{ Area in cells expected to change in 2015 : } \\
\hline & FR & PL & $\mathrm{RF}$ & WTR & WET & WD & WR & $\mathrm{CW}$ & GR & BS & CLT & BLT \\
\hline FR & 30,442 & 22,126 & 12 & 26 & 3 & 2999 & 545 & 74,534 & 12,465 & 5337 & 27,846 & 907 \\
\hline PL & 30,033 & 96,362 & 21 & 26 & 4 & 1526 & 265 & 39,509 & 43,679 & 6769 & 49,248 & 2426 \\
\hline RF & 177 & 55 & 847 & 10 & 374 & 1033 & 958 & 184 & 2407 & 1534 & 4058 & 399 \\
\hline WTR & 13 & 40 & 4 & 2132 & 1687 & 243 & 283 & 1 & 662 & 1526 & 554 & 158 \\
\hline WET & 835 & 5323 & 35 & 122 & 8879 & 4911 & 5727 & 2858 & 10,131 & 14,225 & 8850 & 578 \\
\hline WD & 3259 & 2531 & 3141 & 36 & 3406 & 150,938 & 119,760 & 4206 & 122,233 & 149,969 & 72,599 & 18,598 \\
\hline WR & 4209 & 3489 & 312 & 1 & 123 & 21,613 & 67,174 & 15,584 & 104,434 & 171,807 & 79,069 & 18,544 \\
\hline CW & 21,183 & 26,753 & 27 & 6 & 49 & 17,764 & 10,174 & 153,702 & 98,476 & 65,929 & 206,090 & 14,360 \\
\hline GR & 11,629 & 35,770 & 49 & 0 & 10,054 & 91,847 & 64,129 & 67,501 & 599,338 & 315,549 & 421,688 & 35,914 \\
\hline BS & 16,350 & 42,719 & 18 & 2 & 1094 & 159,713 & 52,099 & 126,528 & 317,696 & 362,890 & 305,895 & 12,483 \\
\hline CLT & 13,756 & 19,074 & 363 & 6 & 5293 & 90,991 & 66,651 & 66,827 & 432,309 & 329,053 & 533,105 & 36,848 \\
\hline BLT & 780 & 766 & 224 & 0 & 4366 & 13,728 & 5463 & 3132 & 38,892 & 20,333 & 48,204 & 17,077 \\
\hline
\end{tabular}

FR: Forest, PL: Plantation, RF: Riverine forest, WTR: Water, WET: Wetland, WD: Woodland, GR: Grassland, WR: Wooded rock, CW: Cultivated woodland, BS: Bushland, CLT: Cultivated land, BLT: Built up.

overall classification accuracies of $99.79 \%, 98.43 \%$, and $99.25 \%$ respectively, for 1990, 2005, and 2015 with their corresponding Kappa statistics of 0.99, 0.98 and 0.99 respectively (Table 5 ). It is recommended that Kappa value for a good classification performance should be more than 0.80 (Jensen, 2005; Lillesand et al., 2004) and the minimum level of promoted classification overall accuracy in identification of land use classes should be at least $85 \%$ (Anderson, 1976). 
Table 5. Classification accuracy.

\begin{tabular}{cccc}
\hline Year & 1990 & 2005 & 2015 \\
\hline Overall accuracy (\%) & 99.79 & 98.43 & 99.25 \\
Kappa statistic & 0.99 & 0.98 & 0.99 \\
\hline
\end{tabular}

\subsubsection{Land Use and Land Cover Change Analysis}

The land use and land cover maps for the year 1990, 2005 and 2015 are presented in Figure 3. Generally, maps show variation in land use and land cover coverage between time periods. Table 6 presents the coverage of each land use and land cover class between 1990 and 2005 and between 2005 and 2015. The extent of LULCC including the area change, percentage area change, annual rate of change and percentage annual rate of change for the Little Ruaha River Catchment are summarized. The increased and decreased amount is represented by positive $(+)$ and negative (-) signs respectively.

The results indicate that for the period between 1990 and 2005 the area under Forest which occupied 39,872 ha (6.26\%) in 1990, decreased to 22,957 ha (3.6\%), indicating a decrease of about $-42.2 \%$ from its original coverage. Likewise, riverine forest and woodland decreased from $5878 \mathrm{ha}(0.92 \%)$ and 109,692 ha (17.22\%) to 2746 ha $(0.43 \%)$ and 72,809 ha (11.43\%) respectively, showing a decrease of $-53.28 \%$ and $-33.62 \%$ for riverine forest and woodland respectively. Water and wetland areas declined from $1752 \mathrm{ha}(0.28 \%)$ and $19,157 \mathrm{ha}(3.01 \%)$ to $1202 \mathrm{ha}(0.19 \%)$ and $11,785 \mathrm{ha}(1.85 \%)$ indicating a loss of $-31.39 \%$ for water and $-38.48 \%$ for wetland between 1990 and 2005. At the same time, cultivated land and built up area showed an increase from 106,782 ha(16.76\%) in 1990 to 109,047 ha (17.12\%) in 2005 and from 9408 ha (1.48\%) to 11,674 ha (1.83\%) respectively, indicating a gain of about $+2.12 \%$ and $+24.09 \%$ respectively.

For the period between 2005 and 2015, the Forest, riverine forest, woodland, water and wetland declined to 15,950 ha $(2.50 \%), 1083$ ha $(0.17 \%), 58,554$ ha (9.19\%), $757 \mathrm{ha}(0.1 \%)$ and 5622 ha $(0.88 \%)$ respectively, indicating percentage loss of $-30.52 \%,-60.56 \%,-19.58 \%, 45.34 \%$, and $-52.30 \%$ respectively. For the same period of time, cultivated land and built up area increased to 143,468 ha (22.52\%) and 13,765 ha $(2.16 \%)$ respectively, indicating a gain of $+31.57 \%$ for cultivated land and $+17.91 \%$ for built up area. The area under Forest decreased at a rate of -1127.67 ha/year (-2.83\%/year) over a period of 15 year (1990-2005), and $-700.70 \mathrm{ha} /$ year $(-3.05 \% / y e a r)$ over a period of 10 years (2005-2015), likewise, riverine forest, woodland showed a similar trend of decline for both time periods.

The overall land use land cover change from 1990 to 2015 indicate that forest, riverine forest, water, wetland and woodland has declined by $60 \%, 82 \%, 63 \%$, $71 \%$, and $47 \%$ respectively from their original coverage, while plantation, grassland, bushland, cultivated land and built up area increased by $18 \%, 25 \%, 44 \%$, $34 \%$ and $46 \%$ respectively. Result shows that woodland, forest, and wetland are the most altered ecosystem where by annually decline at the rate of 2045.52 


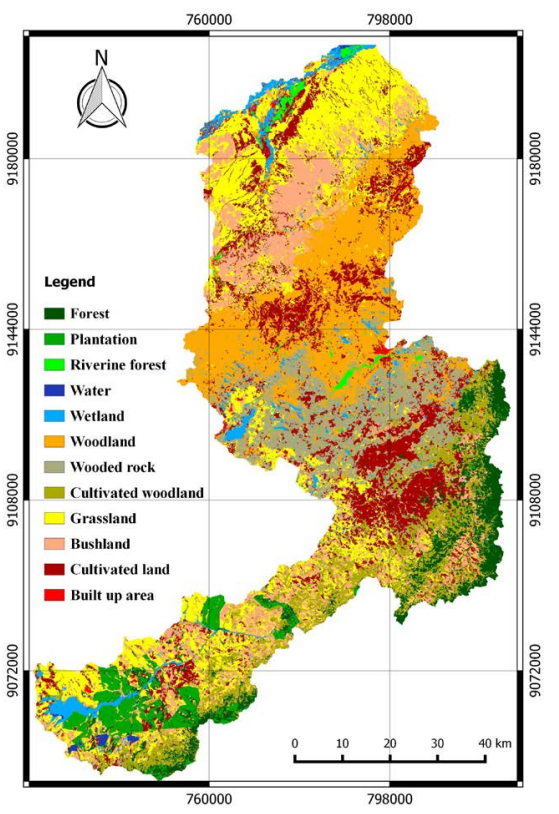

(a)

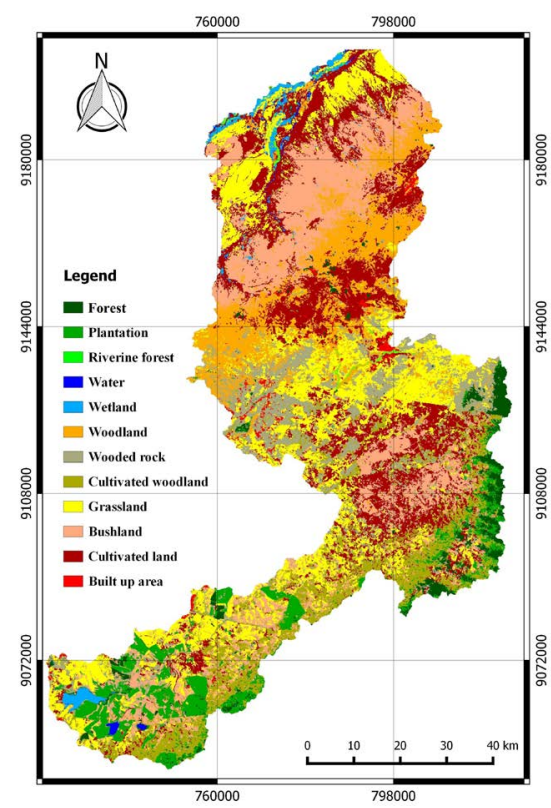

(b)

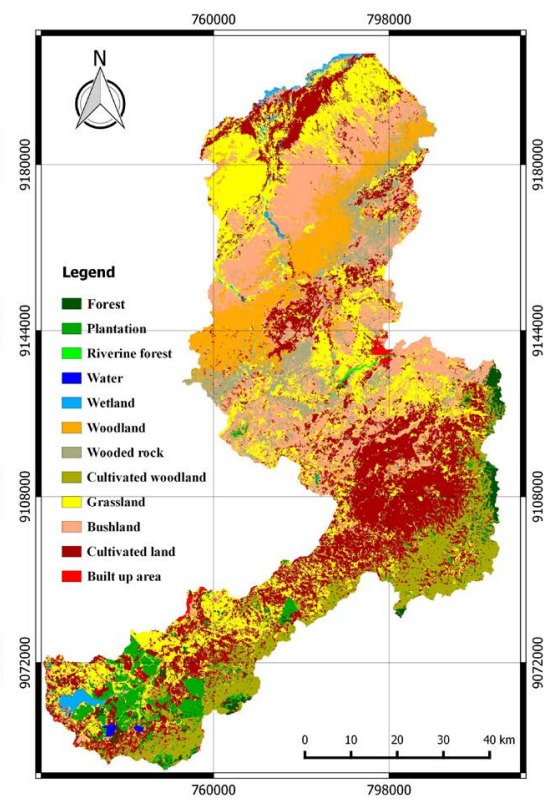

(c)

Figure 3. Classified images of Little Ruaha River Catchment for years (a) 1990 (b) 2005 (c) 2015.

Table 6. Cover area, changed area and rate of change between 1990/2005 and 2005/2015.

\begin{tabular}{|c|c|c|c|c|c|c|c|c|c|c|c|c|c|c|c|}
\hline Years & 199 & & 200 & & 201 & & & $1990-200$ & & & 2005-201 & & & $1990-20$ & \\
\hline LULC & $\begin{array}{l}\text { Cover } \\
\text { area } \\
\text { (ha) }\end{array}$ & $\%$ & $\begin{array}{l}\text { Cover } \\
\text { area } \\
\text { (ha) }\end{array}$ & $\%$ & $\begin{array}{l}\text { Cover } \\
\text { area } \\
\text { (ha) }\end{array}$ & $\%$ & $\begin{array}{l}\text { Change } \\
\text { area } \\
\text { (ha) }\end{array}$ & $\begin{array}{c}\% \\
\text { Change }\end{array}$ & $\begin{array}{l}\text { Annual } \\
\text { rate of } \\
\text { change }\end{array}$ & $\begin{array}{c}\text { Change } \\
\text { area } \\
\text { (ha) }\end{array}$ & $\begin{array}{c}\% \\
\text { Change }\end{array}$ & $\begin{array}{l}\text { Annual } \\
\text { rate of } \\
\text { change }\end{array}$ & $\begin{array}{c}\text { Change } \\
\text { area } \\
\text { (ha) }\end{array}$ & $\begin{array}{c}\% \\
\text { Change }\end{array}$ & $\begin{array}{l}\text { Annual } \\
\text { rate of } \\
\text { change }\end{array}$ \\
\hline FR & 39,872 & 6.26 & 22,957 & 3.6 & 15,950 & 2.5 & $-16,915$ & -42.42 & -1127.67 & -7007 & -30.52 & -700.70 & $-23,922$ & -60.00 & -956.88 \\
\hline PL & 20,632 & 3.24 & 34,068 & 5.35 & 24,285 & 3.81 & 13,436 & +65.12 & +895.73 & -9783 & -28.72 & -978.30 & +3653 & +17.71 & 146.12 \\
\hline RF & 5878 & 0.92 & 2746 & 0.43 & 1083 & 0.17 & -3132 & -53.28 & -208.80 & -1663 & -60.56 & -166.30 & -4795 & -81.58 & -191.80 \\
\hline WTR & 1752 & 0.28 & 1202 & 0.19 & 657 & 0.1 & -550 & -31.39 & -36.67 & -545 & -45.34 & -54.50 & -1095 & -62.50 & -43.80 \\
\hline WET & 19,157 & 3.01 & 11,785 & 1.85 & 5622 & 0.88 & -7372 & -38.48 & -491.47 & -6163 & -52.30 & -616.30 & $-13,535$ & -70.65 & -541.40 \\
\hline WD & 109,692 & 17.22 & 72,809 & 11.43 & 58,554 & 9.19 & $-36,883$ & -33.62 & -2458.87 & $-14,255$ & -19.58 & -1425.50 & $-51,138$ & -46.62 & -2045.52 \\
\hline WR & 60,288 & 9.46 & 75,121 & 11.79 & 43,767 & 6.87 & $+14,833$ & +24.60 & +988.87 & $-31,354$ & -41.74 & -3135.40 & -16521 & -27.40 & -660.84 \\
\hline $\mathrm{CW}$ & 57,368 & 9.01 & 54,517 & 8.56 & 55,300 & 8.68 & -2851 & -4.97 & -190.07 & +783 & +1.44 & +78.30 & -2068 & -3.60 & -82.72 \\
\hline GR & 118,784 & 18.65 & 129,797 & 20.38 & 148,795 & 23.36 & $+11,013$ & +9.27 & +734.20 & $+18,998$ & +14.64 & +1899.80 & $+30,011$ & +25.27 & +1200.44 \\
\hline BS & 87,394 & 13.72 & 111,284 & 17.47 & 125,759 & 19.74 & $+23,890$ & +27.34 & +1592.67 & $+14,475$ & +13.01 & +1447.50 & $+38,365$ & +43.90 & +1534.60 \\
\hline CLT & 106,782 & 16.76 & 109,047 & 17.12 & 143,470 & 22.52 & +2265 & +2.12 & +151.00 & $+34,423$ & +31.57 & +3442.30 & $+36,688$ & +34.36 & +1467.52 \\
\hline BLT & 9408 & 1.48 & 11,674 & 1.83 & 13,765 & 2.16 & +2266 & +24.09 & +151.07 & +2091 & +17.91 & +209.10 & +4357 & +46.31 & +174.28 \\
\hline TOTAL & 637,007 & 100 & 637,007 & 100 & 637,007 & 100 & & & & & & & & & \\
\hline
\end{tabular}

FR: Forest, PL: Plantation, RF: Riverine forest, WTR: Water, WET: Wetland, WD: Woodland, WR: Wooded rock, CLT: Cultivated land, CW: Cultivated woodland, GR: Grassland, BS: Bushland, BLT: Built up area.

ha/year, $956.88 \mathrm{ha} /$ year and $541.40 \mathrm{ha} /$ year respectively. Riverine forest decline at the rate of $191.80 \mathrm{ha} /$ year while water bodies decline by $43.80 \mathrm{ha} /$ year. 


\subsubsection{Transformation of Different Land Covers in the Little Ruaha River Catchment}

The overall gain and loss and the net change of each land use and land cover category between the period 1990-2005, 2005-2015 and 1990-2015 are summarised in Table 7, and change detection matrix showing the transformation of each land use category presented in Tables 8-10.

The results, clearly reflecting the dynamics of land cover classes in the study area. Forest, Woodland and Wetland were found to be the most transformed ecosystems. As illustrated in Table 7, between 1990 and 2015 forest gain 7893 ha while lose 31,820 ha, corresponding to a net loss of $-23,927$ ha; woodland gains 28,623 ha and lose 79,766 ha corresponding to a net loss of $-51,143$ ha followed by wetland which experienced the gain of 2419 ha and lose 15,956 ha equivalents to a net loss of $-13,537$ ha. Cultivated land, grassland, bushland and built up area was found to have consistently net gain of 36,690 ha, 30,014 ha, 38,370 ha and 4356 ha respectively.

Land covers transition matrix present transformation of each land use category. The numbers in brackets indicates the cover area which remained unchanged and others number indicate the flow of cover that changed from one cover to other cover categories. The results have reviled that all land cover categories changed with varying magnitudes. Major changes that have been noted between 1990 and 2015 include: 16,155 ha of forest was transformed to cultivated woodland and 6035 ha to cultivated land. 23,937 ha of woodland was changed to bushland; 19,510 ha to grassland and 11,588 ha to cultivated land while 4235 ha of wetland was transformed to bushland, 3016 ha to grassland and 2635 ha to cultivated land. Results implying there is encroachment of forest, woodland and wetland by human activities including agriculture.

Table 7. The overall gain and loss of each land use/land cover category.

\begin{tabular}{cccccccccc}
\hline \multirow{2}{*}{ Land cover } & \multicolumn{3}{c}{$1990-2005$} & \multicolumn{3}{c}{ 2005-2015 } & \multicolumn{3}{c}{$1990-2015$} \\
\cline { 2 - 11 } & Gain (ha) & Loss (ha) & $\begin{array}{c}\text { Net change } \\
\text { (ha) }\end{array}$ & Gain (ha) & Loss (ha) & $\begin{array}{c}\text { Net change } \\
\text { (ha) }\end{array}$ & Gain (ha) & $\begin{array}{c}\text { Loss (ha) } \\
\text { Net change } \\
\text { (ha) }\end{array}$ \\
\hline Forest & 13,324 & 30411 & $-17,087$ & 10,909 & 18,097 & -7188 & 7893 & 31,820 & $-23,927$ \\
Plantation & 21,535 & 8473 & 13,062 & 13,839 & 23,240 & -9401 & 15,620 & 11,964 & 3656 \\
Riverine forest & 2133 & 5166 & -3033 & 715 & 2424 & -1709 & 597 & 5391 & -4794 \\
Water & 256 & 772 & -516 & 42 & 481 & -439 & 56 & 1149 & -1093 \\
Wetland & 7290 & 13,911 & -6621 & 2331 & 9045 & -6714 & 2419 & 15,956 & $-13,537$ \\
Woodland & 32,064 & 63,850 & $-31,786$ & 33,202 & 53,145 & $-19,943$ & 28,623 & 79,766 & $-51,143$ \\
Wooded rock & 61,171 & 38,551 & 22,620 & 29,222 & 68,227 & $-39,005$ & 33,975 & 50,498 & $-16,523$ \\
Cultivated woodland & 38,067 & 39,811 & -1744 & 36,315 & 36,521 & -206 & 38,422 & 40,491 & -2069 \\
Grassland & 63,623 & 81,933 & $-18,310$ & 97,763 & 53,286 & 44,477 & 98,151 & 68,137 & 30,014 \\
Bushland & 74,190 & 45,742 & 28,448 & 89,438 & 76,243 & 13,195 & 99,072 & 60,702 & 38,370 \\
Cultivated land & 75,977 & 65,508 & 10,469 & 96,410 & 69,242 & 27,168 & 101,471 & 64,781 & 36,690 \\
Builtup area & 12,470 & 7972 & 4498 & 10,685 & 10,920 & -235 & 12,530 & 8174 & 4356 \\
\hline
\end{tabular}


Table 8. Change detection matrix for the period of 1990 to 2005.

\begin{tabular}{|c|c|c|c|c|c|c|c|c|c|c|c|c|c|}
\hline \multirow{2}{*}{$\begin{array}{l}\text { Cover in } \\
1990(\mathrm{Ha})\end{array}$} & \multicolumn{13}{|c|}{ Cover in $2005(\mathrm{Ha})$} \\
\hline & FR & PL & RF & WTR & WET & WD & WR & CW & GR & BS & CLT & BLT & TOTAL \\
\hline FR & $(9238)$ & 10,721 & 15 & 11 & 27 & 837 & 3615 & 8298 & 652 & 3522 & 2611 & 102 & 39,649 \\
\hline PL & 2333 & $(12,020)$ & 1 & 2 & 2 & 295 & 1630 & 1122 & 675 & 1959 & 429 & 25 & 20,493 \\
\hline RF & 517 & 111 & $(652)$ & 21 & 658 & 1371 & 419 & 177 & 623 & 35 & 1044 & 190 & 5818 \\
\hline WTR & 88 & 50 & 135 & $(839)$ & 245 & 49 & 44 & 1 & 40 & 3 & 100 & 17 & 1611 \\
\hline WET & 1154 & 1207 & 962 & 107 & $(4610)$ & 1882 & 5084 & 818 & 460 & 1149 & 955 & 133 & 18,521 \\
\hline WD & 1743 & 654 & 631 & 10 & 1560 & $(46,048)$ & 18545 & 1410 & 12,922 & 8239 & 15203 & 2933 & 109,898 \\
\hline WR & 519 & 391 & 27 & 0 & 10 & 4752 & $(21,414)$ & 6503 & 14,210 & 3112 & 6682 & 2345 & 59,965 \\
\hline $\mathrm{CW}$ & 3043 & 3484 & 7 & 1 & 9 & 1067 & 8440 & $(17,282)$ & 5232 & 7275 & 10,362 & 891 & 57,093 \\
\hline GR & 847 & 1953 & 47 & 28 & 1045 & 7105 & 6351 & 6359 & $(39,609)$ & 29,644 & 25,821 & 2733 & 121,542 \\
\hline BS & 1458 & 1841 & 5 & 2 & 1147 & 3503 & 6593 & 7278 & 12270 & $(41,197)$ & 10,890 & 755 & 86,939 \\
\hline CLT & 1316 & 1087 & 108 & 49 & 1364 & 9930 & 9769 & 5843 & 15,301 & 18,395 & $(40,786)$ & 2346 & 106,294 \\
\hline BLT & 306 & 36 & 195 & 25 & 1223 & 1273 & 681 & 258 & 1238 & 857 & 1880 & (1212) & 9184 \\
\hline TOTAL & 22,562 & 33,555 & 2785 & 1095 & 11,900 & 78,112 & 82,585 & 55,349 & 103,232 & 115,387 & 116,763 & 13,682 & 637,007 \\
\hline
\end{tabular}

FR: Forest, PL: Plantation, RF: Riverine forest, WTR: Water, WET: Wetland, WD: Woodland, GR: Grassland, WR: Wooded rock, CW: Cultivated woodland, BS: Bushland, CLT: Cultivated land, BLT: Built up. Numbers in brackets indicate cover areas that remained unchanged between the two periods of 1990 and 2005.

Table 9. Change detection matrix for the period of 2005 to 2015.

\begin{tabular}{|c|c|c|c|c|c|c|c|c|c|c|c|c|c|}
\hline \multirow{2}{*}{$\begin{array}{l}\text { Cover in } \\
2005(\mathrm{Ha})\end{array}$} & \multicolumn{13}{|c|}{ Cover in $2015(\mathrm{Ha})$} \\
\hline & FR & PL & RF & WTR & WET & WD & WR & $\mathrm{CW}$ & GR & BS & CLT & BLT & TOTAL \\
\hline FR & $(4867)$ & 2105 & 72 & 14 & 373 & 970 & 439 & 6344 & 2425 & 1415 & 3587 & 353 & 22,964 \\
\hline PL & 4559 & $(10,312)$ & 14 & 14 & 50 & 390 & 265 & 8043 & 2970 & 1103 & 5524 & 308 & 33,552 \\
\hline RF & 32 & 0 & $(362)$ & 0 & 325 & 217 & 113 & 6 & 522 & 356 & 739 & 114 & 2786 \\
\hline WTR & 3 & 7 & 0 & $(615)$ & 80 & 8 & 1 & 3 & 25 & 220 & 79 & 55 & 1096 \\
\hline WET & 7 & 62 & 2 & 8 & $(2855)$ & 569 & 244 & 25 & 2513 & 2302 & 3203 & 110 & 11,900 \\
\hline WD & 398 & 296 & 433 & 1 & 142 & $(24,969)$ & 14699 & 777 & 9650 & 18,084 & 7384 & 1281 & 78,114 \\
\hline WR & 1532 & 2508 & 118 & 5 & 120 & 6639 & $(14,356)$ & 4820 & 16,270 & 23,001 & 11,344 & 1870 & 82,583 \\
\hline CW & 1851 & 2717 & 1 & 0 & 2 & 1636 & 1286 & $(18,830)$ & 7772 & 6856 & 13,476 & 924 & 55,351 \\
\hline GR & 560 & 1439 & 40 & 0 & 303 & 1982 & 3218 & 2850 & $(49,946)$ & 15,125 & 24,765 & 3004 & 103,232 \\
\hline BS & 1053 & 3356 & 1 & 0 & 62 & 15,262 & 6828 & 7758 & 17,436 & $(39,742)$ & 23,959 & 528 & 115985 \\
\hline CLT & 873 & 1314 & 15 & 0 & 769 & 4578 & 1556 & 5448 & 34,816 & 17,735 & $(46,520)$ & 2138 & 115,762 \\
\hline BLT & 41 & 35 & 19 & 0 & 105 & 951 & 573 & 241 & 3364 & 3241 & 2350 & $(2762)$ & 13,682 \\
\hline TOTAL & 15,776 & 24,151 & 1077 & 657 & 5186 & 58,171 & 43,578 & 55,145 & 147,709 & 129,180 & 142,930 & 13,447 & 637,007 \\
\hline
\end{tabular}

FR: Forest, PL: Plantation, RF: Riverine forest, WTR: Water, WET: Wetland, WD: Woodland, GR: Grassland, WR: Wooded rock, CW: Cultivated woodland, BS: Bushland, CLT: Cultivated land, BLT: Built up. Numbers in brackets indicate cover areas that remained unchanged between the two periods of 2005 and 2015. 
Table 10. Change detection matrix for the period of 1990 to 2015.

\begin{tabular}{|c|c|c|c|c|c|c|c|c|c|c|c|c|c|}
\hline \multirow{2}{*}{$\begin{array}{l}\text { Cover in } \\
1990(\mathrm{Ha})\end{array}$} & \multicolumn{13}{|c|}{ Cover in $2015(\mathrm{Ha})$} \\
\hline & FR & PL & $\mathrm{RF}$ & WTR & WET & WD & WR & $\mathrm{CW}$ & GR & BS & CLT & BLT & TOTAL \\
\hline FR & $(8058)$ & 4796 & 3 & 6 & 1 & 650 & 118 & 16,155 & 2702 & 1157 & 6035 & 197 & 39,878 \\
\hline PL & 2071 & $(8668)$ & 1 & 2 & 0 & 105 & 18 & 2725 & 3012 & 467 & 3396 & 167 & 20,632 \\
\hline RF & 85 & 27 & (487) & 5 & 180 & 498 & 461 & 88 & 1160 & 739 & 1956 & 192 & 5878 \\
\hline WTR & 3 & 9 & 1 & $(602)$ & 375 & 54 & 63 & 0 & 147 & 339 & 123 & 35 & 1751 \\
\hline WET & 248 & 1585 & 11 & 36 & (3133) & 1462 & 1705 & 851 & 3016 & 4235 & 2635 & 172 & 19089 \\
\hline WD & 520 & 404 & 501 & 6 & 544 & $(29,939)$ & 19,116 & 671 & 19,510 & 23,937 & 11,588 & 2969 & 109,705 \\
\hline WR & 507 & 420 & 38 & 0 & 15 & 2604 & (9797) & 1877 & 12581 & 20,697 & 9525 & 2234 & 60,295 \\
\hline $\mathrm{CW}$ & 1861 & 2351 & 2 & 1 & 4 & 1561 & 894 & $(16,883)$ & 8653 & 5793 & 18,109 & 1262 & 57,374 \\
\hline GR & 752 & 2312 & 3 & 0 & 650 & 5937 & 4145 & 4363 & $(50,660)$ & 20,397 & 27,257 & 2321 & 118,797 \\
\hline BS & 959 & 2506 & 1 & 0 & 64 & 9371 & 3057 & 7424 & 18,640 & $(26,702)$ & 17,948 & 732 & 87,404 \\
\hline CLT & 840 & 1164 & 22 & 0 & 323 & 5555 & 4069 & 4080 & 26,391 & 20,088 & $(42,013)$ & 2249 & 106,794 \\
\hline BLT & 47 & 46 & 14 & 0 & 263 & 826 & 329 & 188 & 2339 & 1223 & 2899 & (1236) & 9410 \\
\hline TOTAL & 15,951 & 24,288 & 1084 & 658 & 5552 & 58,562 & 43,772 & 55,305 & 148,811 & 125,774 & 143,484 & 13,766 & 637,007 \\
\hline
\end{tabular}

EF: Forest, PL: Plantation, RF: Riverine forest, WTR: Water, WET: Wetland, WD: Woodland, GR: Grassland, WR: Wooded rock, CW: Cultivated woodland, BS: Bushland, CLT: Cultivated land, BLT: Built up. Numbers in brackets indicate cover areas that remained unchanged between the two periods of 1990 and 2015.

Summary on changed and unchanged cover areas between 1990 and 2015 are presented in Table 11. The percentage changed indicates the percentage area of a particular cover which changed to other covers while the percentage unchanged represents the percentage area of the original area of a particular cover which remained unchanged for a given period (Kashaigili \& Majaliwa, 2010). Results shows, the forest cover changed to other forms by $80 \%$, while woodland changed by $72 \%$, cultivated woodland by $71 \%$, wetland and water bodies changed by $83 \%$ and $66 \%$ respectively, bushland changed by $69 \%$, grassland by $57 \%$, built-up land and cultivated land changed by $87 \%$ and $61 \%$ respectively. However, some cover areas remained unchanged between 1990 and 2015.

\subsection{Future Change in Land Use and Land Cover in the Little Ruaha River Catchment}

\section{1) CA-Markov model validation results}

Using VALADATE tool, IDRISI gave the standard Kappa of 0.83, Kappa for no information of 0.89 , Kappa for grid-cell level location of 0.86 and Kappa for stratum-level location of 0.864 (Figure 4) which are all more than 0.7 , as recommended by (Wen, 2008) that the Kappa index of the valid model is $>70 \%$.

\section{2) Probability of future change in land use and land cover}

The conditional probability maps that express the probability that each pixel will belong to designated class in the next 25 years are presented in Figure 5(a)-(1). They are called conditional probability maps since this probability is conditional on their current state. Thus, these maps are a cartographical presentation of the transition probability matrix. 
Table 11. Changed and unchanged individual land cover between 1990 and 2015.

\begin{tabular}{ccccc}
\hline Cover type & $\begin{array}{c}\text { Area unchanged } \\
\text { (ha) }\end{array}$ & $\begin{array}{c}\text { Percent unchanged } \\
(\%)\end{array}$ & $\begin{array}{c}\text { Area changed } \\
\text { (ha) }\end{array}$ & $\begin{array}{c}\text { Percent changed } \\
\text { (\%) }\end{array}$ \\
\hline Forest & 8058 & 20 & 31,814 & 80 \\
Plantation & 8668 & 42 & 11,966 & 58 \\
Riverine forest & 487 & 8 & 5391 & 92 \\
Water & 602 & 34 & 1150 & 66 \\
Wetland & 3204 & 17 & 15,956 & 83 \\
Woodland & 29,939 & 27 & 79,466 & 72 \\
Wooded rock & 9797 & 16 & 50,498 & 84 \\
Cultivated woodland & 16,883 & 29 & 40,492 & 71 \\
Grassland & 50,660 & 43 & 68,138 & 57 \\
Bushland & 26,702 & 31 & 60,702 & 69 \\
Cultivated land & 42,013 & 39 & 64,782 & 61 \\
Built-up land & 1236 & 13 & 8173 & 87 \\
\hline
\end{tabular}

\begin{tabular}{|c|c|c|c|c|c|c|c|}
\hline \multicolumn{4}{|c|}{ Multiples of Base Resolution (MBR): 1} & $\times 1$ & \multicolumn{3}{|c|}{ Information of Quantity } \\
\hline \multicolumn{2}{|l|}{ Information of Location } & No[n] & & & Medium[m] & & Perfect[p] \\
\hline \multicolumn{2}{|l|}{ Perfect $[\mathrm{P}[\mathrm{x})]$} & 0.4481 & & & 0.9801 & & 1.0000 \\
\hline \multicolumn{2}{|l|}{ PerfectStratum[K[x]] } & 0.4481 & & & 0.9801 & & 1.0000 \\
\hline \multicolumn{2}{|l|}{ MediumGrid[M[x]] } & 0.3732 & & & 0.8985 & & 0.8912 \\
\hline \multicolumn{2}{|l|}{ MediumStratum[H[x]] } & 0.0769 & & & 0.3792 & & 0.3779 \\
\hline \multicolumn{2}{|l|}{$\mathrm{No}[\mathrm{N}[\mathrm{x})]$} & 0.0769 & & & 0.3792 & & 0.3779 \\
\hline AgreeGridcell & $=0.5193$ & & Disagree & Uantity & $=0.0199$ & Kstandard & $=0.8365$ \\
\hline AgreeStrata & $=0.0000$ & & Disagree & Strata & $=0.0000$ & Kno & $=0.8900$ \\
\hline A.greeQuantity & $=0.3023$ & & Disagree & Ġidcell & $=0.0816$ & Klocation & $=0.8642$ \\
\hline AgreeChance & $=0.0769$ & & & & & KlocationSt & $\mathrm{ta}=0.8642$ \\
\hline
\end{tabular}

Figure 4. The spatio-statistical output generated in validation process.

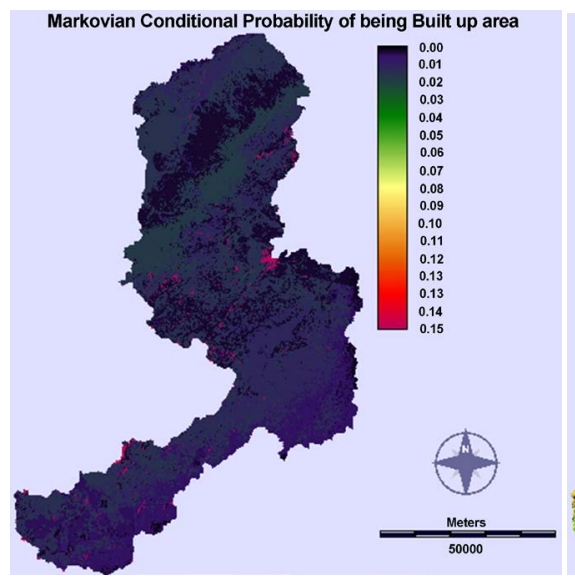

(a)

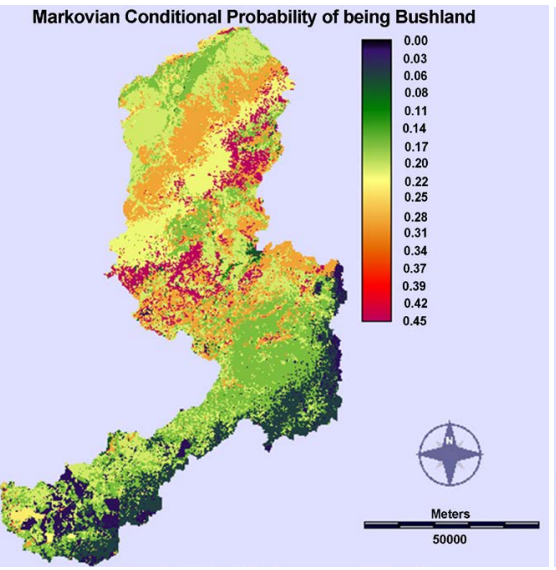

(b)

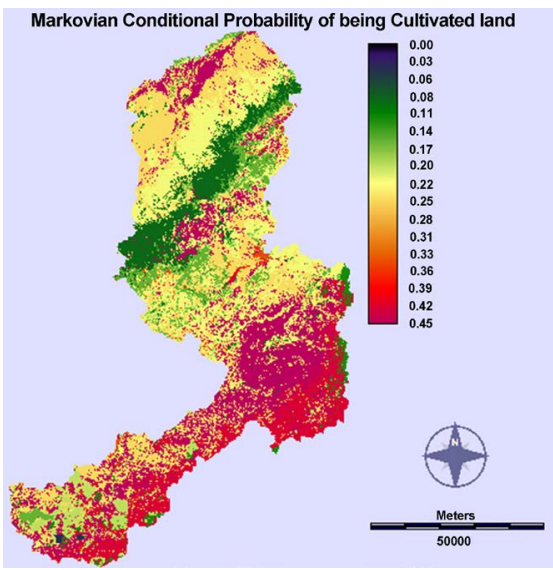

(c) 


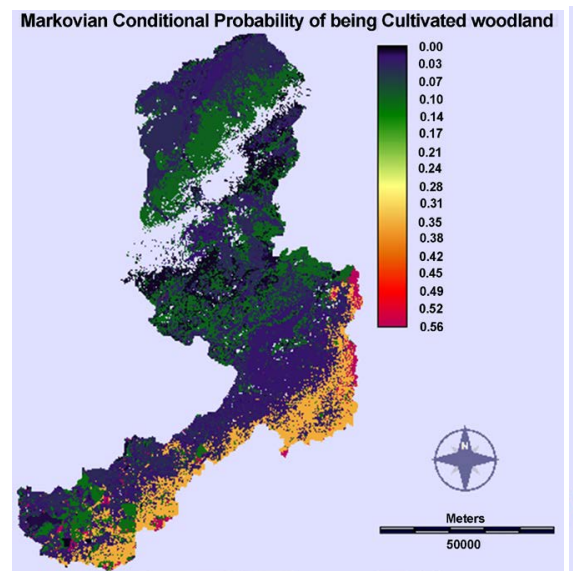

(d)

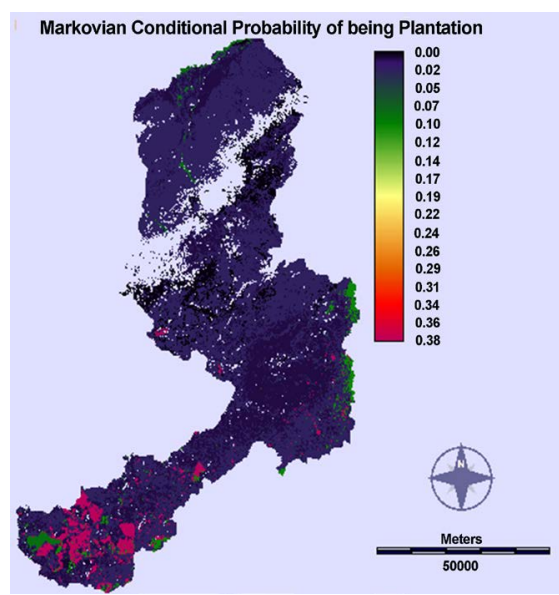

(g)

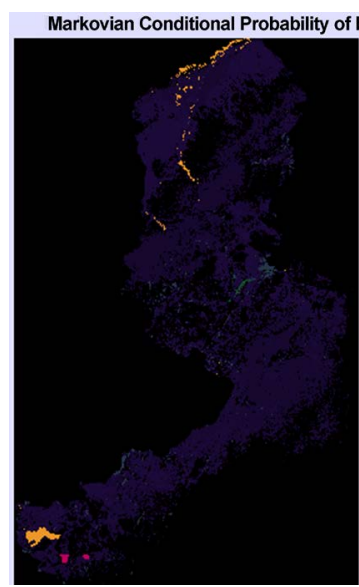

(j)

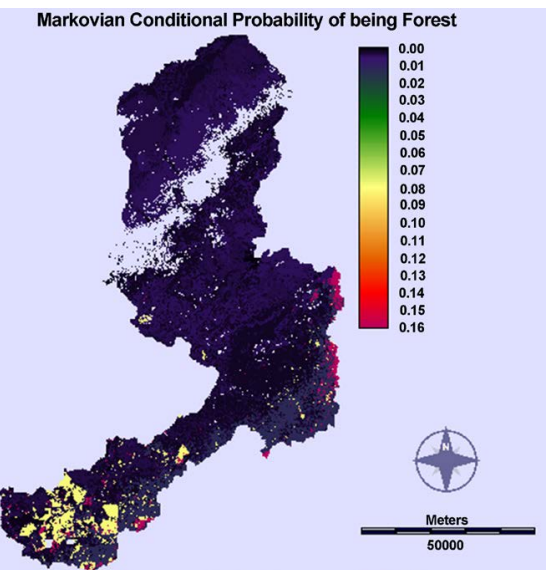

(e)

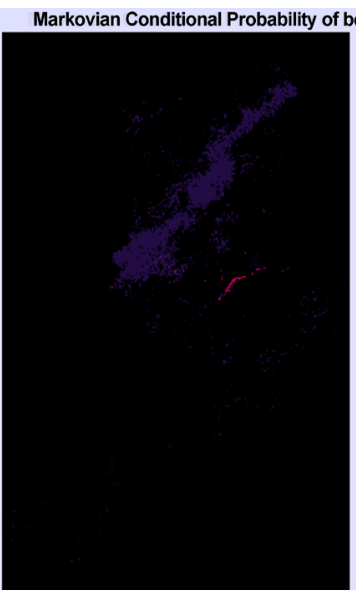

(h)

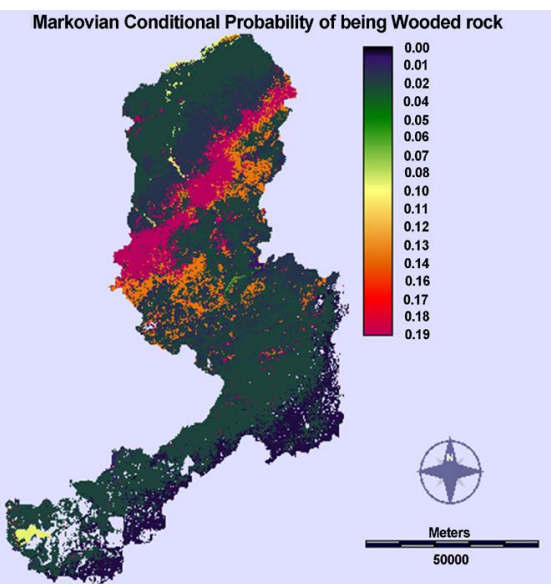

(k)

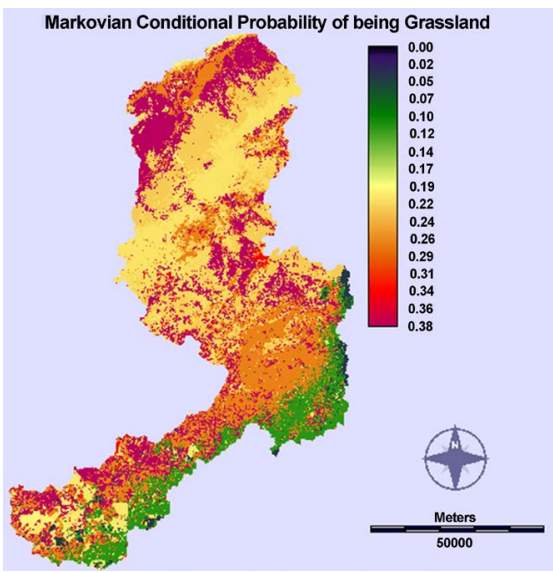

(f)

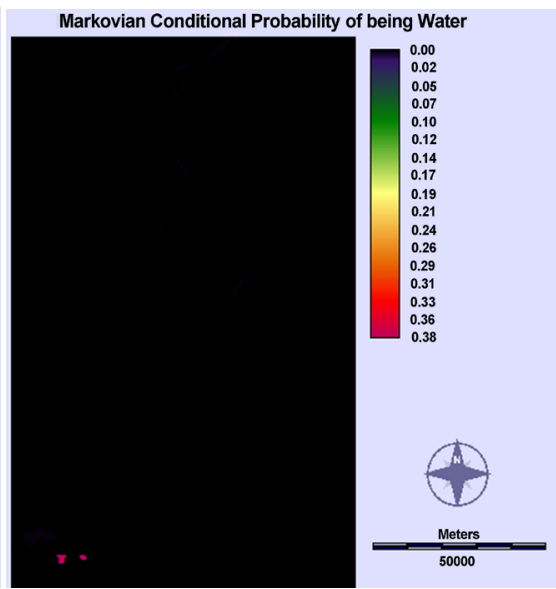

(i)

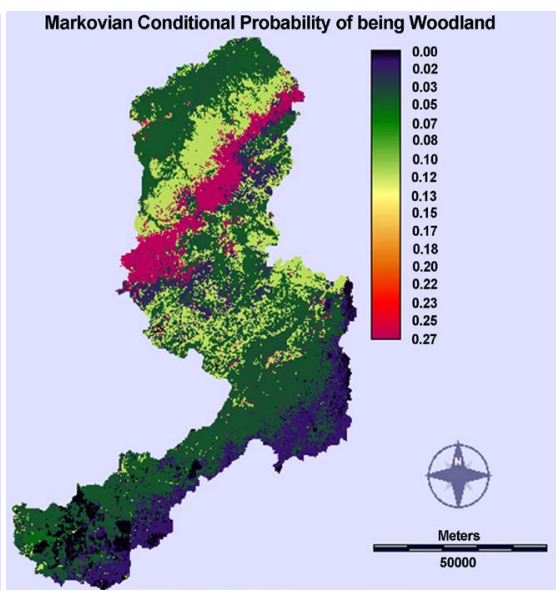

(1)

Figure 5. Conditional probability images for each land use/cover. (a) Markovia Conditional probability of being Forest; (b) Markovian Conditional probability of being plantation; (c) Markovian Conditional probability of being riverine forest; (d) Markovian Conditional probability of being water; (e) Markovian Conditional probability of being wetland; (f) Markovian Conditional probability of being woodland; ( $\mathrm{g}$ ) Markovian Conditional probability of being wooded rock; (h) Markovian Conditional probability of being cultivated woodland; (i) Markovian Conditional probability of being grassland; (j) Markovian Conditional probability of being bushland; (k) Markovian Conditional probability of being cultivated land; (l) Markovian Conditional probability of being built up area. 


\section{3) Spatial distribution of predicted land use land cover 2040}

The land use land cover map for the next 25 years is presented in Figure 6. The statistical analysis of land use land cover for the predicted year 2040 illustrated in Table 12. An overall change in land use and land cover in all the 25 years of prediction revealed that, the grassland will dominate by occupying $25 \%$ which is equivalent to 160,422 ha of the catchment followed by cultivated land which is expected to cover $24.82 \%$ equivalent to 158,132 ha. Forest coverage will decrease from 15,950 ha $(2.5 \%)$ existing in 2015 to 11,936 ha $(1.87 \%)$, riverine forest will decrease from 1083 ha $(0.17 \%)$ experienced in 2015 to 461 ha $(0.07 \%)$, woodland will decrease from 157,621 ha (24.74\%) existing in 2015 to 135,446 ha (21.26\%). Projected decrease in water bodies and wetland whereby water bodies coverage and wetland expected to decrease to 211 ha $(0.03 \%)$ and 3,183 ha $(0.5 \%)$ respectively.

\section{Discussion}

A detailed land cover change analysis map from this study allowed us to better understand the historical and future land cover transitions in the Little Ruaha River catchment. The analysis showed that activities associated with agriculture being the dominant driver of conversion of other land covers especially forest and wetlands.

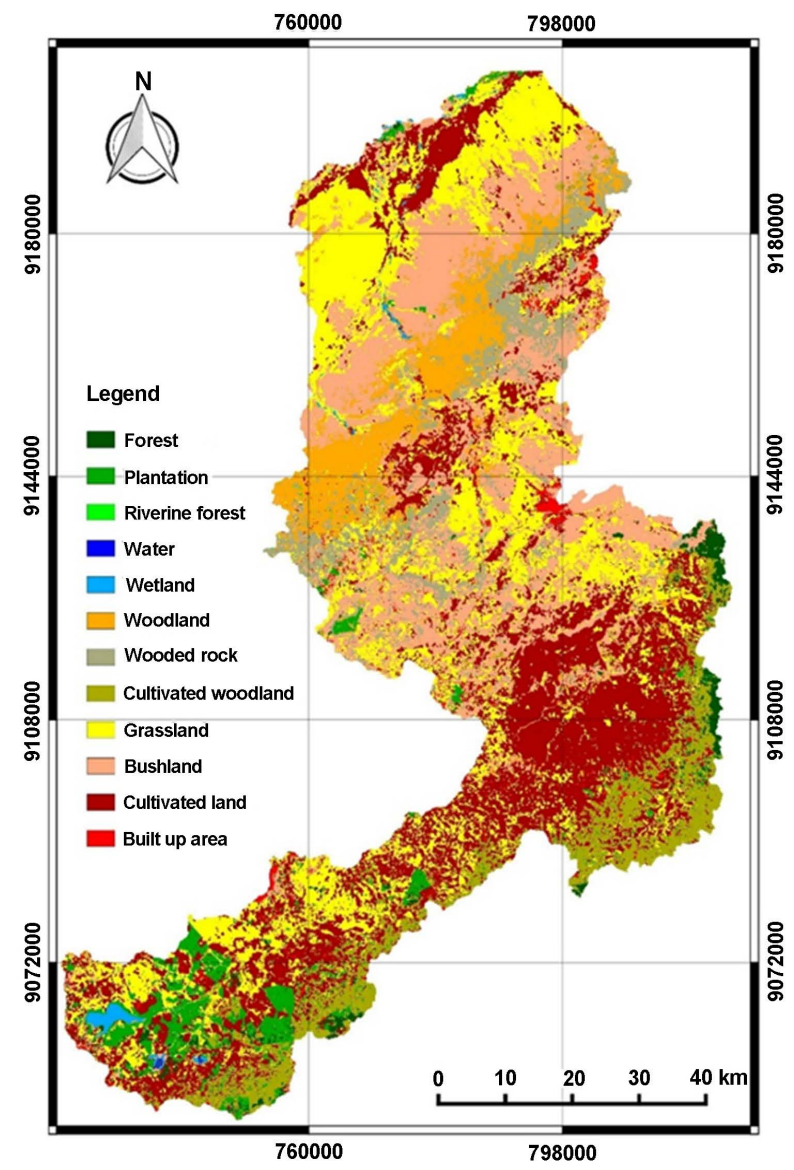

Figure 6. Predicted land use/cover map of Little Ruaha River catchment of 2040 . 
Table 12. Percentage of predicted land use/cover based on CA-Markov model.

\begin{tabular}{ccc}
\hline LULC & \multicolumn{2}{c}{2040} \\
\hline Forest & Area (Ha) & Coverage (\%) \\
Plantation & 11,936 & 1.87 \\
Riverine forest & 22,950 & 3.60 \\
Water & 461 & 0.07 \\
Wetland & 211 & 0.03 \\
Woodland & 3183 & 0.50 \\
Wooded rock & 50,158 & 7.87 \\
Cultivated woodland & 35,387 & 5.56 \\
Grassland & 49,901 & 7.83 \\
Bushland & 160,422 & 25.18 \\
Cultivated land & 130,023 & 20.41 \\
Built up & 158,132 & 24.82 \\
Total & 14,243 & 2.24 \\
& 637,007 & 100
\end{tabular}

From the results (Figure 7) revealed a rapid decrease in forest cover which is direct associated to human encroachments for timber, firewood and medicine and clear and burning for expansion of agricultural farms. This has also been emphasized by local people during ground truthing that fire burning and deforestation has been a serious problem in recent years. Deforestation and degradation in the Little Ruaha River catchment are also influenced by rapid population growth (Figure 8) that leads farmers to expand their farmlands and settlement to sustain the livelihood.

The liner decrease in area under water could be attributable to destruction of riparian zones due to valley-bottom farming locally known as Vinyungu (Figure 9). Bottom valley cultivation (Vinyungu) is a most dominating traditional irrigation farming observed during field survey. Vinyungu, a type of farming practiced in dry season play a great role in converting wetland into cultivated land in turn threaten the sustainability of wetlands to supply vital ecosystem services especially water discharge. During ground truthing most of farmers observed to practice Vinyungu cultivation in dry season. Other factors for the observed decrease of water resource are drying up of water bodies due to decrease in rainfall and increase in competitors' user.

These trends are predicted to increase over the next 25 years. This expansion will result in largescale conversion of forest and wetlands to cultivated land, which will have negative impacts not only to human being but also on the wildlife especially in Ruaha National Park. Nevertheless, is legally protected that means all anthropogenic activities are restricted within, but this important ecosystem can be impacted through blockage of wildlife corridors by agricultural development 


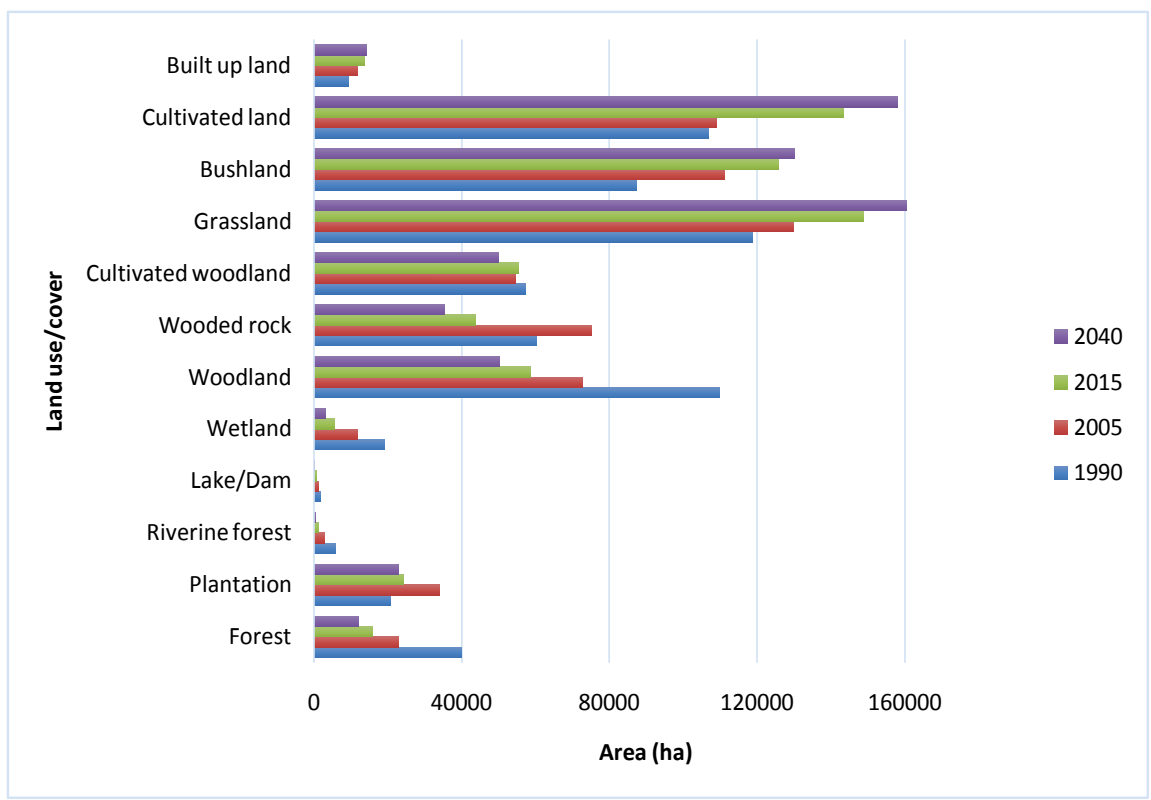

Figure 7. Historical and Predicted Spatial Coverage in Land use/cover in the Little Ruaha River catchment.

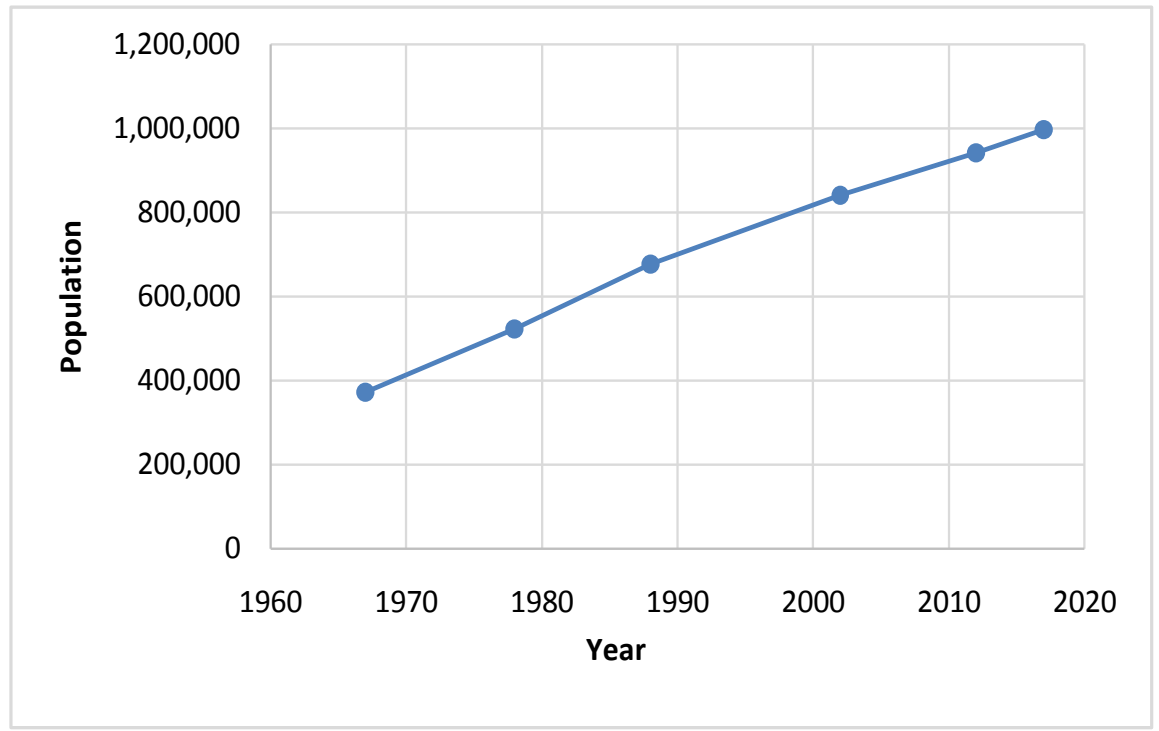

Figure 8. Iringa regional population. Sources: Iringa Region Socio-economic Profile (NBS) (Council, 2013).
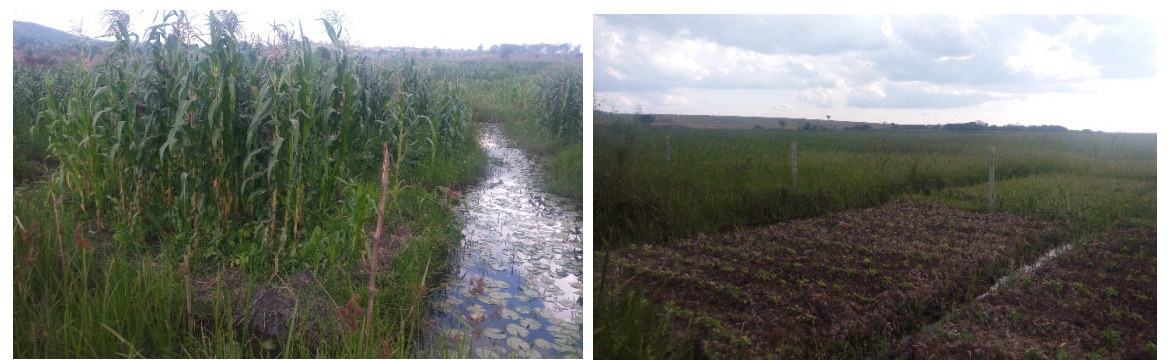

Figure 9. Bottom valley cultivation practices (Vinyungu). 
which in turn can result into wildlife-farmers conflict. Sustainably managing agricultural expansion into ecologically sensitive areas will be important for maintaining wildlife and water resources for the sustainability of the Little Ruaha River catchment. Results from this study support previous findings conducted in southern highland watersheds which found a significant alteration of important and sensitive ecosystems includes forest covers and water bodies (Kashaigili, 2008; Kashaigili \& Majaliwa, 2010).

\section{Conclusion}

This study investigated the land use and land cover dynamics in the Little Ruaha River catchment. It highlights the importance of integrating remote sensing with the accurate classification algorithms for precisely modelling and generating information that could be used to overcome the land use and land cover change problems for the sustainability of the catchment. Furthermore, the study simulating and predicting the future spatial distribution in land use and land cover of the Little Ruaha River catchment based on CA Markov model.

The findings from the study have revealed that the Little Ruaha River Catchment has undergone a notable change in terms of land use and land cover whereby forest, woodland and wetland were found to be the most altered ecosystems. During ground truthing several anthropogenic activities associated to land use land cover transformation were observed which includes forest encroachments, forest fires, expansion of agricultural farms and urbanization as well as unsustainable cultivation resulted to destruction of riparian zones and wetlands. Results from CA Markov model discovered that for the next 25 years (2040) the grassland will dominate in the catchment followed by cultivated land.

The study concludes that, there has been significant changes in land use and cover in the catchment. In order to overcome the land use and land cover change problems for the sustainability of the catchment, the study recommends the holistic system approach in management and utilization of catchment resources. Involvement of many actors and stakeholders to create a multidisciplinary team to ensure sustainable management of Little Ruaha River catchment. Official alone will not be possible to control such large landscape. Authority should take responsible for the whole scene of management while the villagers should also take responsibility in obeying and follow the law and policies governing the proper management of natural resources. Finally, the study recommends on the need of the follow up study to assess the likely impacts of observed LULC change on water balance of the catchment, so as to address whether there will be sufficient water to meet the various water needs in the present and future.

\section{Acknowledgements}

The authors highly acknowledge the financial support from a research program on Water Land and Ecosystem (WLE), an ambitious 12 years CGIAR's Research Program led by the International Water Management Institute (IWMI) as well as all the individuals who were consulted during the study. 


\section{Conflicts of Interest}

The authors declare no conflicts of interest regarding the publication of this paper.

\section{References}

Adger, W. N. (2007). Successful Adaptation to Climate Change across Scales. Global Environmental Change, 15, 77-86. https://doi.org/10.1016/j.gloenvcha.2004.12.005

Al-Bakri, J. T., Duqqah, M., \& Brewer, T. (2013). Application of Remote Sensing and GIS for Modeling and Assessment of Land Use/Cover Change in Amman/Jordan. Journal of Geographic IFRormation System, 5, 509-519. https://doi.org/10.4236/igis.2013.55048

Almeida, C. M. D., Monteiro, A. M. V., Câmara, G., Soares-Filho, B. S., Cerqueira, G. C., Pennachin, C. L., \& Batty, M. (2005). GIS and Remote Sensing as Tools for the Simulation of Urban Land-Use Change. International Journal of Remote Sensing, 26, 759-774. https://doi.org/10.1080/01431160512331316865

Anderson, J. R. (1976). A Land Use and Land Cover Classification System for Use with Remote Sensor Data (pp. 28). Geological Survey Professional Paper No. 964, Washington DC: U.S. Government Printing Office. https://doi.org/10.3133/pp964

Araya, Y. H., \& Cabral, P. (2010). Analysis and Modeling of Urban Land Cover Change in Setúbal and Sesimbra, Portugal. Remote Sensing, 2, 1549-1563. https://doi.org/10.3390/rs2061549

Buck, L. (2012). SAGCOT Green Growth Leaders Workshop Report (p. 61). Dare es Salaam, Tanzania: Government Printer.

Congalton, R. G. (1991). A Review of Assessing the Accuracy of Classifications of Remotely Sensed Data. Remote Sensing Environment, 37, 35-46. https://doi.org/10.1016/0034-4257(91)90048-B

Congedo, L. (2016). Semi-Automatic Classification Plugin Documentation. Release, 4, 29.

Council, I. D. (2013). Iringa Region Socio-Economic Profile. Iringa, Tanzania.

Jensen, J. R. (2004). Introductory Digital Image Processing: A Remote Sensing Perspective (3rd ed., pp. 316). New York: Prentice-Hall, Inc.

Jensen, J. R. (2005). Introductory Digital Image Processing: A Remote Sensing Perspective. Prentice Hall, NJ: Pearson.

Jensen, J. R., \& Lulla, K. (1987). Introductory Digital Image Processing: A Remote Sensing Perspective. Geocarto International, 2, 65. https://doi.org/10.1080/10106048709354084

Kashaigili, J. J. (2008). Impact of Land Use Land Cover Changes on Flow Regimes of the Usangu Wetland and the Great Ruaha River, Tanzania. Physics and Chemistry of the Earth, Parts $A / B / C, 33,640-647$.

http://www.researchgate.net/publication/223730643 Impacts of land-use and landcove rchanges on flow regimes of the Usangu wetland and the GreatRuahaRiver Tanzania https://doi.org/10.1016/j.pce.2008.06.014

Kashaigili, J. J., \& Majaliwa, A. M. (2010). Intergrated Assessment of Land Use Land Cover Changes in the Malagarasi River Catchment in Tanzania. Journal of physics and Chemistry of the Earth, 35, 730-741. https://doi.org/10.1016/j.pce.2010.07.030

Kashaigili, J. J., McCartney, M. P., Mahoo, H. F., Lankford, B. A., Mbilinyi, B. P., Yawson, D. K., \& Tumbo, S. D. (2006). Use of a Hydrological Model for Environmental Management of the Usangu Wetlands, Tanzania (pp. 48). Research Report No. 104, Colombo, Sri Lanka: International Water Management Institute. 
Li, R. Q., Dong, M., Cui, J. Y., Zhang, L. L., Cui, Q. G., \& He, W. M. (2007). Quantification of the Impact of Land-Use Changes on Ecosystem Services: A Case Study in Pingbian County, China. Environmental Monitoring and Assessment, 128, 503-510. https://doi.org/10.1007/s10661-006-9344-0

Lillesand, T. M., \& Kiefer, R. W. (2002). Remote Sensing and Image Interpretation (4th ed.). New York: John Wiley and Sons.

Lillesand, T. M., Kiefer, R. W., \& Chipman, J. W. (2004). Remote Sensing and Image Interpretation (5th ed.). New York: John Wiley \& Sons, Inc.

Lillesand, T., Kiefer, R. W., \& Chipman, J. (2014). Remote Sensing and Image Interpretation. New York: John Wiley \& Sons.

Lin, Y P., Wu, P J., \& Hong, N M. (2008). The Effects of Changing the Resolution of Land-Use Modeling on Simulations of Land-Use Patterns and Hydrology for a Catchment Land-Use Planning Assessment in $\mathrm{Wu}-\mathrm{Tu}$, Taiwan. Landscape and Urban Planning, 87, 54-66. https://doi.org/10.1016/j.landurbplan.2008.04.006

Majule, A. E. (2013). Establishing Land Use/Cover Change Patterns over the Last Two Decades and Associated Factors for Change in Semi-Arid and Sub Humid Zones of Tanzania. Open Journal of Ecology, 3, 445-453. https://doi.org/10.4236/oje.2013.36051

Milder, J. C., Buck, L. E., Hart, A. K., \& Scherr, S. (2012). The SAGCOT Greenprint: A Green Growth Investment Framework for the Southern Agricultural Growth Corridor of Tanzania (p. 87).

Milder, J. C., Hart, A. K., \& Buck, L. E. (2013). Applying an Agriculture Green Growth Approach in the SAGCOT Clusters: Challenges and Opportunities in Kilombero, Iheni and Mbarali.

Ohri, A., \& Poonam, O. (2012). Urban Sprawl Mapping and Land Use Change Detection Using Remote Sensing and Geographic IFRormation Systems. International Journal of Remote Sensing and GIS, 1, 12-25.

Rutherford, J., Kobryn, H., \& Newsome, D. (2015). A Case Study in the Evaluation of Geotourism Potential through Geographic Information Systems: Application in a Geology-Rich Island Tourism Hotspot. Current Issues in Tourism, 18, 267-285. https://doi.org/10.1080/13683500.2013.873395

Soka, G., \& Nzunda, N. (2014). Application of Remote Sensing and Developed Allometric Models for Estimating Wood Carbon Stocks in a North-Western Miombo Woodland Landscape of Tanzania. Journal of Ecosystems, 2014, Article ID: 714734. https://doi.org/10.1155/2014/714734

Wang, T., Wu, W., Xue, X., Han, Z., Zhang, W., \& Sun, Q. (2004). Spatial-Temporal Changes of Sandy Desertified Land during Last 5 Decades in Northern China. Acta Geographica Sinica-Chinese Edition, 59, 203-212.

Wen, W. (2008). Wetland Change Prediction Using Markov Cellular Automata Model in Lore Lindu National Park Central Sulawesi Province (pp. 90). Bogor: Bogor Agricultural University.

Wu, N., \& Silva, E. (2010). Artificial/Intelligence Solutions for Urban Land Dynamics: A Review. Journal of Planning Literature, 24, 246-265.

https://doi.org/10.1177/0885412210361571 